\title{
ISOLASI DAN IDENTIFIKASI SENYAWA FLAVONOID DARI BATANG CIPLUKAN (Physalis angulata L.)
}

${ }^{1}$ Dadan Ridwanuloh, ${ }^{2}$ Fadilah Syarif

${ }^{1}$ Prodi Farmasi Fakultas Teknologi dan Ilmu Komputer Universitas Buana Perjuangan

Karawang (dadanridwanuloh@ubpkarawang.ac.id)

${ }^{2}$ Prodi Farmasi Fakultas Teknologi dan Ilmu Komputer Universitas Buana Perjuangan

Karawang (m.15fadilahsyarif@mhs.ubpkarawang.ac.id)

\begin{abstract}
ABSTRAK
Pemanfaatan tumbuhan di Indonesia banyak digunakan sebagai obat-obatan herbal dan sebagai upaya mempertahankan kesehatan masyarakat. Dari penelitian yang telah dilakukan, baik secara in vitro maupun in vivo, didapatkan informasi bahwa Ciplukan memiliki aktivitas sebagai antihiperglikemi, antibakteri, antivirus, imunostimulan dan imunosupresan (imunomodulator), antiinflamasi, antioksidan, dan sitotoksik. Selain itu dari berbagai laporan tumbuhan ini memiliki banyak khasiat tidak lain karena memiliki kandungan senyawa kimia yang fungsinya dapat mengobati suatu penyakit, salah satu senyawa kimia yang terkandung dalam tanaman Ciplukan ini adalah senyawa flavonoid. Berdasarkan dari hal ini maka dilakukanlah penelitian dengan isolasi dan identifikasi senyawa flavonoid yang terkandung dalam batang tanaman Ciplukan, Physalis angulata L. Metode yang digunakan adalah Uji Fitokomia, Kromatograpi Lapis Tipis, Kromatografi Kolom, dan Spektrofotometri UV-Vis. Hasil uji fitokimia menunjukan bahwa batang Ciplukan mengandung senyawa Kuinon, flavonoid, saponin, dan monosesquiterpeoid, dan polifenol. Uji KLT dengan eluen n-heksan-etil asetat (7:3) menunjukan kromatogram berwarna biru dengan Rf $0.8 \mathrm{~cm}$. Beberapa fraksi hasil Kromatografi Kolom kemudian di Spektrofotometri UV-Vis menunjukan senyawa tersebut merupakan senyawa flavonoid jenis flavanon.
\end{abstract}

Kata Kunci : Senyawa Flavonoid, Ciplukan (Physalis angulata L.).

\begin{abstract}
The use of plants in Indonesia is widely used as herbal medicines and as an effort to maintain public health. One type of plant that is used as herbal medicines is the Ciplukan plant. In addition, from various reports of this plant has many other properties because it contains chemical compounds whose function is to treat a disease, one of the chemical compounds contained in this Ciplukan plant is a flavonoid compound. Based on this, a study was conducted with the isolation and identification of flavonoid compounds contained in the stem of the Ciplukan plant, Physalis angulata L. The methods used were Phytochomia Test, Thin Layer Chromatography, Column Chromatography, and UV-Vis Spectrophotometry. Phytochemical test results show that the Ciplukan stem contains Kuinon, flavonoid, saponin, and monosesquiterpeoid compounds, and polyphenols. TLC test with nhexane-ethyl acetate (7:3) eluent showed a blue chromatogram with $\mathrm{Rf} 0.8 \mathrm{~cm}$. Several fractions of the results of the chromatography column later on UV-Vis Spectrophotometry showed that the compound was a flavonoid type of flavanone.
\end{abstract}

Keynote : Flavonoid, Ciplukan (Physalis angulata L.). 


\section{PENDAHULUAN}

Ciplukan, Physalis angulata L. adalah tumbuhan asli Amerika yang kini telah tersebar secara luas di daerah tropis di dunia. Ciplukan mengandung senyawasenyawa aktif yang ada antara lain saponin (pada tunas), flavonoid (daun dan tunas), polifenol, dan fisalin (buah), Withangulatin A (buah), asam palmitat dan stearat (biji), alkaloid (akar), Asam Chlorogenik (batang dan daun), tannin (buah), kriptoxantin (buah), vitamin C dan gula (buah) (Ramesh \& Mahalakshmi, 2014). Dari penelitian salah satu tanaman yang diteliti sebagai antikanker adalah tanaman Ciplukan (Physalis angulata $\mathrm{L}$ ).

Berdasarkan dari hasil fitokimia beberapa referensi bahwa kandungan kimia daun tanaman Ciplukan mengandung senyawa Fisalin dan Withanolid yang disinyalir dari berbagai laporan mengandung aktivitas antikanker (Widodo et al., 2010). Selain itu dari berbagai laporan tumbuhan ini memiliki banyak khasiat tidak lain karena memiliki kandungan senyawa kimia yang fungsinya dapat mengobati suatu penyakit, salah satu senyawa kimia yang terkandung dalam tanaman Ciplukan ini adalah senyawa flavonoid. Flavonoid merupakan salah satu metabolit sekunder yang terdapat pada tumbuhan. Senyawa ini dapat digunakan sebagai anti mikroba, obat infeksi pada luka, anti jamur, anti virus, anti kanker, dan anti tumor. Selain itu flavonoid juga dapat digunakan sebagai anti bakteri, anti alergi, sitotoksik, dan anti hipertensi (Sriningsih, 2008). Akan tetapi, belum dilaporkan jenis senyawa flavonoid yang terdapat pada batang tanaman Ciplukan. Oleh karena itu perlu diketahui jenis senyawa flavonoid yang terdapat pada batang tanaman Ciplukan.

\section{METODE PENELITIAN}

\subsection{Tempat dan Waktu Penelitian}

Penelitian ini adalah penelitian eksperimen yang dilaksanakan di Laboratorium

Bahan Alam Program Studi Farmasi Fakultas Teknologi dan Ilmu Komputer, Universitas Buana Perjuangan Karawang pada bulan Desember 2018 sampai Februari 2019. 


\subsection{Alat dan Bahan}

\subsubsection{Alat}

Peralatan yang digunakan untuk identifikasi dan karakterisasi senyawa metabolit sekunder yaitu seperangkat alat Maserator, rotary evaporator (Heidolph Laborota 4000), oven, beaker glass, tabung reaksi, batang pengaduk, spatula, botol coklat, kolom kromatografi, neraca analitik, chamber, pipa kapiler, plat KLT, dan lampu UV ( $\lambda 254$ dan $366 \mathrm{~nm}$ ) sebagai pengungkap noda. Untuk proses karakterisasi dengan spektrum ultraviolet digunakan spektrofotometer ultraviolet visible (Shimadzu PharmaSpec UV-1700).

\subsubsection{Bahan}

Bahan-bahan yang digunakan untuk isolasi senyawa metabolit sekunder ialah batang tanaman ciplukan yang didapatkan dari daerah karawang timur. Bahanbahan kimia yang digunakan adalah etanol 96\% sebagai pelarut saat maserasi, etil asetat, dan n-heksan sebagai eluen pada kromatografi lapis tipis dan sebagai pelarut untuk kromatografi kolom. Absorben yang digunakan pada kromatografi kolom adalah silika gel $60 \mathrm{~F}_{254}(0,063-0,200 \mathrm{~mm})$, untuk analisa kromatografi lapis tipis (KLT) digunakan plat jadi yaitu DC-Alufolien Kieselgel $60 \mathrm{~F}_{254}$ Merck (20x20 cm), kertas saring dan aluminium foil. Bahan yang digunakan untuk uji fitokimia yaitu pereaksi Mayer dan Dragendorf dipakai untuk identifikasi alkaloid, pereaksi Lieberman Burchad (anhidrida asetat dan asam sulfat pekat) untuk identifikasi terpenoid dan steroid, (asam klorida pekat dan bubuk Magnesium) untuk identifikasi flavonoid dan besi (III) flourida $\left(\mathrm{FeCl}_{3}\right)$ untuk identifikasi fenolik.

\section{PEMBAHASAN}

\subsection{Determinasi Tanaman}

Determinasi tumbuhan dimaksudkan untuk memperoleh kepastian jenis tumbuhan yang digunakan. Determinasi ini dilakukan di Institut Teknologi Bandung Fakultas Sekolah Ilmu dan Teknologi Hayati. Determinasi dilakukan dengan mencocokkan tanaman dengan ciri-ciri morfologi batang ciplukan yang digunakan penelitian dengan acuan pustaka. Hasil determinasi Nomor 6325/11.CO2.2/PL/2018 menunjukan bahwa tanaman yang digunakan adalah Physalis angulata $\mathrm{L}$. 


\subsection{Ekstraksi Sampel}

Hasil ekstraksi mendapatkan ektrak kental 13.06 gram beraroma tidak khas dan berwarna hijau kehitaman. Persentase rendemen ekstrak yang didapatkan sebesar $6.5 \%$, hal ini tidak sesuai dengan literatur yang menyantakan bahwa rendemen tidak kurang dari 9.65\% (FHI, 2010). Faktor yang mempengaruhi jumlah rendemen yang dihasilkan adalah metode ekstraksi yang digunakan yaitu maserasi, karena maserasi tidak menggunakan bantuan panas (tidak adanya bantuan dari gaya lain), pada metode maserasi ini hanya menggunakan perendaman sehingga tekanan osmosis pelarut kedalam padatan berlangsung statis meskipun telah remaserasi dengan pelarut (Nurasiah, 2009).

\subsection{Parameter Standar}

Uji parameter standar dilakukan terhadap simplisia batang Ciplukan (Physalis angulata L.) yang meliputi susut pengeringan dan kadar air. Hasil uji susut pengeringan merupakan indikator tentang besarnya senyawa yang hilang pada proses pengeringan. Hasil uji susut pengeringan adalah $8 \%$ hasil tersebut sesuai dengan literatur bahwa hasil susut pengeringan tidak boleh melebihi 10\% (FHI, 2008).

Adapun hasil uji kadar air adalah $4.8 \%$, hasil tersebut sesuai dengan literatur bahwa kadar air dalam ekstrak tidak boleh melebihi 10\% (Depkes. RI, 2008), dan tidak boleh lebih dari $11.7 \%$ (FHI, 2010). Hal ini bertujuan untuk menghindari cepatnya pertumbuhan jamur dalam ekstrak (Soetarno dan Soediro, 1997).

\subsection{Skrining Fitokimia}

Skrining fitokimia dilakukan terhadap simplisia dan ekstrak etanol batang Ciplukan. Adapun hasil uji skrining fitokimia serbuk dan ekstrak etanol batang Ciplukan yang diperoleh selanjutnya dilakukan uji pereaksi secara kualitatif seperti pada tabel 4.1 dan 4.2 . 
Tabel 4.1 Hasil Uji Pereaksi Simplisia Batang Ciplukan

\begin{tabular}{|c|c|c|c|c|}
\hline \multirow{2}{*}{ Uji } & \multirow{2}{*}{ Pereaksi } & \multicolumn{2}{|c|}{ Warna } & \multirow{2}{*}{ Ket } \\
\hline & & Pustaka & Hasil & \\
\hline Polifenol & $\mathrm{FeCl}_{3}$ & Coklat kehitaman & $\begin{array}{l}\text { Kuning } \\
\text { kecoklatan, ada } \\
\text { endapan }\end{array}$ & - \\
\hline Kuinon & $\mathrm{NaOH}$ & Kuning tua/jingga & Kuning tua & + \\
\hline Saponin & $\mathrm{HCl}$ & $\begin{array}{l}\text { Busa } 1 \mathrm{~cm} \text { selama } \\
1 \text { menit }\end{array}$ & $\begin{array}{l}\text { Busa } 1 \mathrm{~cm} \text { selama } \\
1 \text { menit }\end{array}$ & + \\
\hline Flavonoid & $\mathrm{Mg}, \mathrm{HCl}$ & $\begin{array}{l}\text { Merah/ jingga/ } \\
\text { kuning }\end{array}$ & Kuning & + \\
\hline $\begin{array}{l}\text { Monoseskuiter } \\
\text { Penoid }\end{array}$ & $\begin{array}{l}\text { Vanilin } \\
\text { Sulfat }\end{array}$ & Warna-warna & Kuning kehijauan & + \\
\hline
\end{tabular}

Tabel 4.2 Hasil Uji Pereaksi Ekstrak Pekat Batang Ciplukan

\begin{tabular}{|c|c|c|c|c|}
\hline \multirow{2}{*}{ Uji } & \multirow{2}{*}{ Pereaksi } & \multicolumn{2}{|c|}{ Warna } & \multirow{2}{*}{$\begin{array}{c}\mathbf{K e} \\
\mathbf{t}\end{array}$} \\
\hline & & Pustaka & Hasil & \\
\hline Polifenol & $\mathrm{FeCl}_{3}$ & $\begin{array}{l}\text { Coklat } \\
\text { kehitaman }\end{array}$ & $\begin{array}{l}\text { Coklat } \\
\text { kehitaman }\end{array}$ & + \\
\hline Kuinon & $\mathrm{NaOH}$ & $\begin{array}{l}\text { Kuning } \\
\text { tua/jingga }\end{array}$ & Kuning tua & + \\
\hline Saponin & $\mathrm{HCl}$ & $\begin{array}{l}\text { Busa } 1 \mathrm{~cm} \\
\text { selama } 1 \text { menit }\end{array}$ & $\begin{array}{l}\text { Busa } 1 \mathrm{~cm} \\
\text { selama } 1 \text { menit }\end{array}$ & + \\
\hline Flavonoid & $\mathrm{Mg}, \mathrm{HCl}$ & $\begin{array}{l}\text { Kuning/ hijau- } \\
\text { hitam }\end{array}$ & Kuning & + \\
\hline $\begin{array}{l}\text { Monoseskuiter } \\
\text { Penoid }\end{array}$ & $\begin{array}{l}\text { Vanilin } \\
\text { Sulfat }\end{array}$ & Warna-warna & $\begin{array}{l}\text { Kuning } \\
\text { kehijauan }\end{array}$ & + \\
\hline
\end{tabular}

Keterangan: $(+)=$ terdeteksi, $(-)=$ tidak terdeteksi

Hasil uji skrining fitokimia menggunakan simplisia dan ekstrak etanol batang Ciplukan seperti yang tercantum dalam tabel di atas menunjukan bahwa batang Ciplukan mengandung senyawa Kuinon, Saponin, Flavonoid, Monoseskuiterpenoid, dan Polifenol. Hal ini dibuktikan dengan hasil uji simplisia batang ciplukan yang mengandung senyawa Kuinon, Saponin, Flavonoid, Monoseskuiterpenoid, sedangkan ekstrak etanol batang Ciplukan juga mengandung senyawa Kuinon, Saponin, Flavonoid, Monoseskuiterpenoid, dan Polifenol. Adanya perbedaan hasil yang didapatkan pada uji Skrining Fitokimia terhadap simplisia dan ekstrak dapat dipengaruhi oleh pelarut yang digunakan saat ekstraksi, yaitu pelarut etanol 96\%, sehingga diduga pelarut tersebut dapat melarutkan senyawa polifenol, yang dapat dibuktikan pada pengujian Skrining Fitokimia menggunakan ekstrak menghasilkan positif mengandung senyawa polifenol. 


\subsection{Kromatografi Lapis Tipis (KLT)}

Dari beberapa uji eluen yang dilakukan terhadap ekstrak kental Etanol, diperoleh bahwa eluen n.heksana-etil asetat (7:3) merupakan eluen yang baik. Hal ini ditunjukan dengan penampakan noda yang jelas dan terpisah dengan baik. Akan tetapi pada hasil uji KLT ini diduga masih mengandung berbagai komponen senyawa yang ditunjukan dengan banyaknya spot noda yaitu spot noda berwarna biru dengan nilai Rf $0.8 \mathrm{~cm}$, spot noda berwarna kuning dengan nilai $\mathrm{Rf} 0.5 \mathrm{~cm}$, dan spot noda berwarna ungu dengan nilai Rf $0.5 \mathrm{~cm}$.

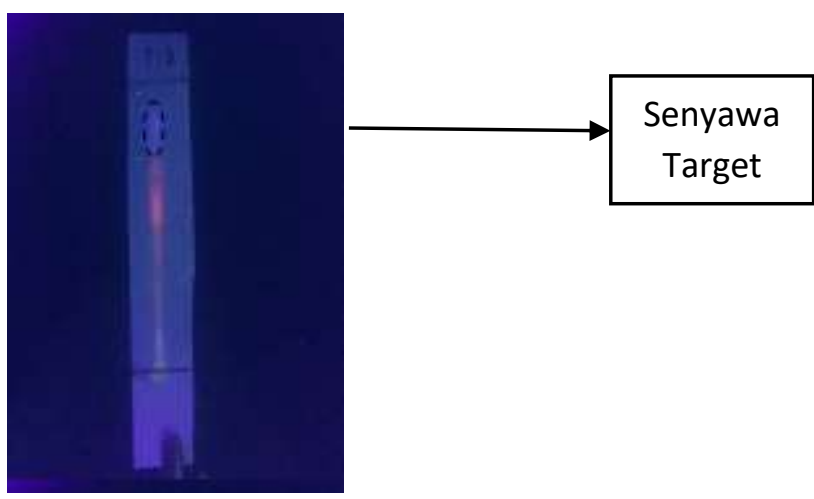

Gambar 4.1. Kromatogram Hasil KLT ekstrak etanol dari batang Ciplukan. Keterangan: Fase Diam: Lempeng KLT, Fase Gerak: n-heksana-etil asetat (7:3) dilihat pada lampu UV dengan panjang gelombang $366 \mathrm{~nm}$, Penampak bercak: Situborat.

\subsection{Isolasi / Fraksinasi}

Isolasi adalah proses pengambilan atau pemisahan senyawa bahan alam dengan menggunakan pelarut yang sesuai (Djamal, 2008). Isolat pada vial ke 1-11 yang telah diuji dengan KLT dengan perbandingan eluen n.heksana-etil asetat (7:3) menghasilkan spot tunggal yang berwarna biru, spot ini dilihat pada lampu UV pada panjang gelombang $366 \mathrm{~nm}$ sehingga senyawa tersebut diduga merupakan senyawa murni golongan flavonoid. Hal ini sesuai dengan pendapat (Achmad, S.A, 1986) yang menyatakan bahwa jika senyawa yang di uji dengan KLT memberikan noda tunggal, maka senyawa hasil isolasi sudah murni. Profil kromatogram identifikasi golongan senyawa flavonoid menunjukan bercak berwarna biru ketika dibaca pada panjang gelombang $366 \mathrm{~nm}$ (Marliana et al., 2005). Kromatogram yang dihasilkan dari fraksi-fraksi hasil Kromatografi Kolom terlihat pada gambar 4.2. 


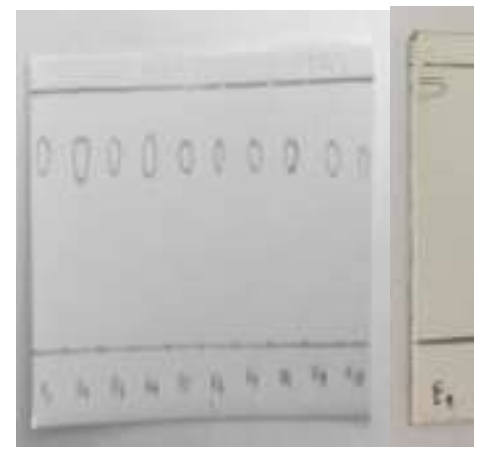

a)

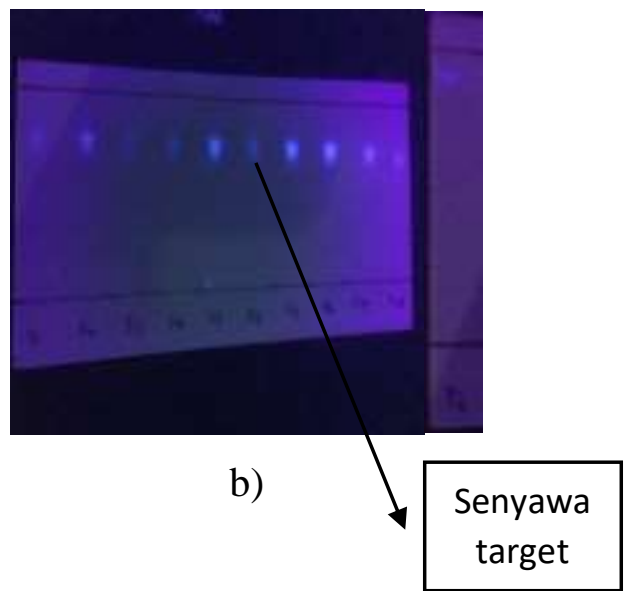

b)

a) Kromatogram Hasil KLT (cahaya tampak), b)

Kromatogram Hasil KLT.

Gambar 4.2. Kromatografi Lapis Tipis (Vial Ke1-11)

Keterangan: Fraksi Vial Ke-1 sampai 11, Fase Diam: Plat Silika Gel

GF254, Fase Gerak: Campuran n.heksana-etil asetat (7:3), dilihat pada lampu UV dengan panjang gelombang $366 \mathrm{~nm}$.

Adapun nilai Rf dari noda yang nampak dapat dilihat pada Tabel 4.3.

Tabel 4.3 Nilai Rf dari noda yang nampak

\begin{tabular}{|c|c|}
\hline Vial Ke- & Nilai Rf \\
\hline $1-9$ & $0,7 \mathrm{~cm}$ \\
\hline 10 & $0,68 \mathrm{~cm}$ \\
\hline 11 & $0,9 \mathrm{~cm}$ \\
\hline
\end{tabular}

Nilai Rf dapat didefinisikan sebagai jarak yang ditempuh oleh komponen dibagi dengan jarak yang ditempuh oleh pelarut. Senyawa dengan nilai Rf yang rendah lebih terdistribusi pada fase diamnya, sedangkan nilai Rf yang tinggi akan terdistribusi pada fase geraknya. Noda dengan nilai Rf yang rendah bersifat lebih polar dibandingkan dengan niali Rf yang tinggi. Oleh karena itu bilangan Rf selalu lebih kecil dari $1 \mathrm{~cm}$. Untuk memaksimalkan pemisahan rentang nilai Rf terletak antara 0.2 sampai $0.8 \mathrm{~cm}$. 


\subsection{Spektrofotometri UV-Vis}

Isolat yang diperoleh dari hasil KLT diidentifikasi secara kualitatif dengan Spektrofotometer UV-Vis. Spektrofotometri UV-Vis digunakan untuk mengetahui nilai absorbansi senyawa pada panjang gelombang maskimal. Pengukuran spektrum dilakukan pada panjang gelombang 200-400 nm. Spektrum khas senyawa flavonoid terdiri atas dua maksimal pada rentang 240-285 nm (pita II) dan 300-550 nm (pita I). Senyawa flavonoid golongan flavanon menurut Markham (1988) memberikan rentang serapan pada panjang gelombang 275-295 nm pada pita II dan 300-330 nm (bahu) pada pita I, hasil analisis menggunakan Spektrofotometri UVVis yang dilakukan Markham dapat dilihat pada gambar 4.3.

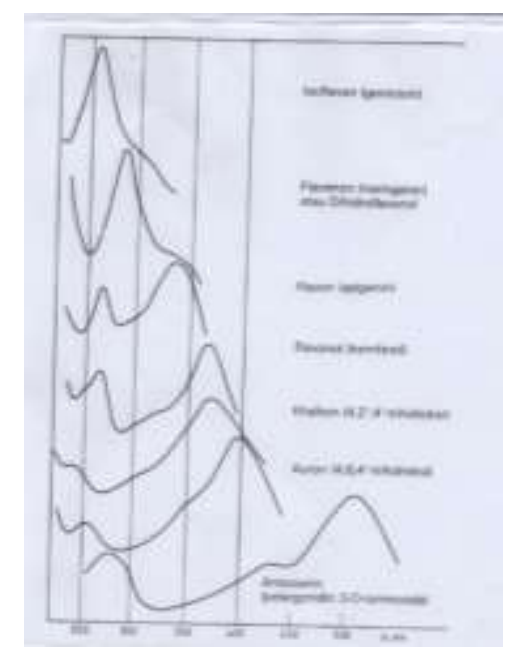

\section{Gambar 4.3. Spektrum UV-Vis Flavonoid dengan Pelarut MeOH (Markham, 1988).}

Hasil analisis menggunakan Spektrofotometri UV-Vis, senyawa isolat dalam fraksi n-heksana menunjukan 2 pita pada serapan maksimum 229,263 nm pada pita II dan bentuk bahu pada 301,902 nm yang merupakan pita I. Senyawa hasil isolasi menunjukan bahwa batang Ciplukan diduga mengandung senyawa flavonoid golongan flavanon, hal tersebut diperlihatkan dengan bentuk spektrum yang hampir sama dengan spektrum flavanon yang yang terdapat dalam pustaka. Hasil analisis menggunakan Spektrofotometri UV-Vis dapat dilihat pada Gambar 4.4. 


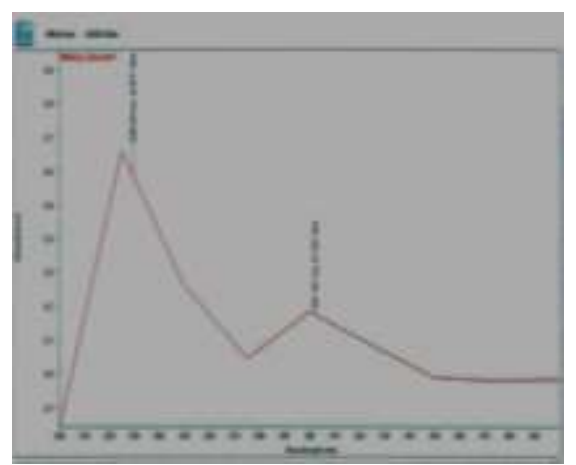

Gambar 4.4. Spektrum Isolat menggunakan Spektrofotometri UV-Vis Keterangan: Spektrum Isolat Fraksi Kromatografi Kolom, Larutan Baku: n.heksana, Interval: $25 \mathrm{~cm}$.

Hasil identifikasi tersebut juga dibuktikan dengan uji Skrining Fitokimia, dimana tujuan dilakukan Uji Skrining Fitokimia ini adalah untuk membuktikan isolat tersebut merupakan senyawa flavonoid berdasarkan regaen yang tepat. Fraksi yang digunakan untuk uji Spektrofotometri UV-Vis diuji dengan penambahan serbuk $\mathrm{Mg}$ dan $0,5 \mathrm{ml} \mathrm{HCl}$ lalu dikocok kuat, adanya larutan yang berwarna kuning yang merupakan positif mengandung senyawa flavonoid (Herborne, 1978). Hasil Uji fitokimia pada isolat dapat dilihat pada Gambar 4.5.

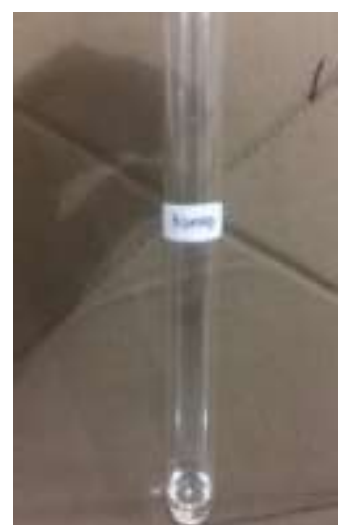

a) Blangko Fraksi Isolat

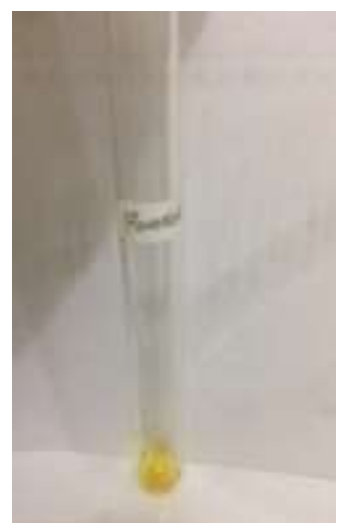

b) Hasil Uji Skrining Fitokimia (Senyawa Flavonoid)

\section{Gambar 4.5. Hasil Fitokimia Fraksi Kromatografi Kolom}

Keterangan: Uji Skrining Fitokimia pada isolat murni Kromatografi Kolom, Reagen: serbuk Mg dan $0.5 \mathrm{ml} \mathrm{HCl}$. 


\section{KESIMPULAN}

Berdasarkan hasil penelitian yang dilakukan pada batang Ciplukan (Physalis angulata L.) maka dapat diambil kesimpulan sebagai berikut:

Terdapat senyawa Flavonoid pada batang Ciplukan. Hal tersebut dibuktikan dengan Uji Fitokimia baik pada simplisia atau ekstrak batang Ciplukan. Adapun jenis senyawa flavonoid yang terdapat pada batang Ciplukan adalah senyawa Flavanon. Hal tersebut dibuktikan dengan hasil Uji Kromatografi Lapis Tipis (KLT) dan Uji Spektrofotometri UV-Vis.

\section{DAFTAR PUSTAKA}

Achamad, S.A. 1986. Kimia Organik Bahan Alam, Materi 4: Ilmu Kimia Flavonoid. Karunia Universitas Terbuka. Jakarta. Hlm 39.

Djamal, Rusdi. (2008). Prinsip-prinsip Dasar Isolasi Dan Identifikasi. Padang: Universitas Baiturrahmah.

Harborne, J.B. 1987. Metode Fitokimia Penuntun Cara Modern Menganalisis Tumbuhan. Penerbit ITB. Bandung.

Kusumaningtyas et al. 2015. Potential Of Ciplukan (Physalis angulate L.) As Source Of Functional Ingredient. Procedia Chemistry 14, hlm 367-372.

Markham, K.R., 1988, Cara Mengidentifikasi Flavonoid. Diterjemahkan Oleh Kosasih Pandawinata, 15, Penerbit ITB, Bandung.

Marliana, D.S., Venty, S., dan Suyono. (2005). Skrining Fitokimia Dan Analisis Kromatografi Lapis Tipis Komponen Bahan Alam Buah Labu Siam (Sechium edule Jacq. Swartz.) Dalam Ekstrak Etanol. Jurnal Biofarmasi. 3(1): 29.

Nurhayati T, Aryanti D, Nurjanah. 2009. Kajian Awal Potensi Ekstrak Spons Sebagai Antioksidan. Jurnal Kelautan Nasional 2:43-51.

Ramesh, B. N., Mahalakshmi, A. M. 2014. Physalis angulata L.: An Ethanopharmacological Review. Indo American Journal of Pharm Research 4 (03), hlm. 1479-1486.

Soetarno, S. dan Soediro, L.S., 1997, Standarisasi Mutu Simplisia Dan Ekstrak Bahan Obat Tradisional, Presidium Temu Ilmiah Nasional Bidang Farmasi.

Supachok, P. \& Vajrodaya, S., Comparative Phytochemistry Of Physalis angulata L. (Family Solanaceae). Short Comunication. Departemetn of Botani, Faculty of Science, Kasetsart University Bangkok. 